省電力形巣光ランブの諸特性 (3)

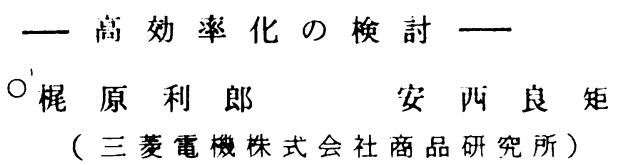

1. はじめに

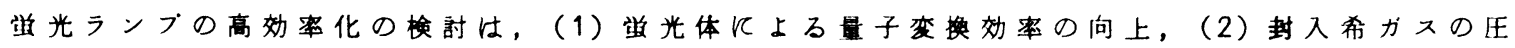

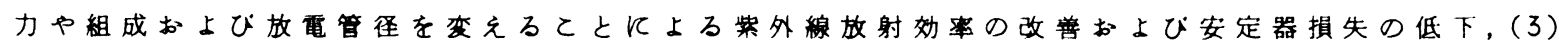

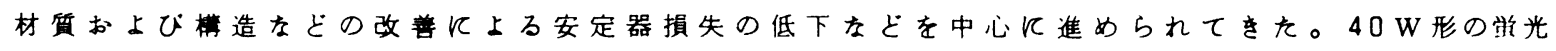

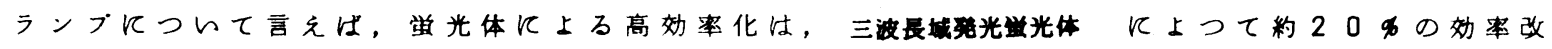

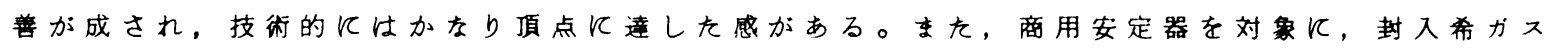

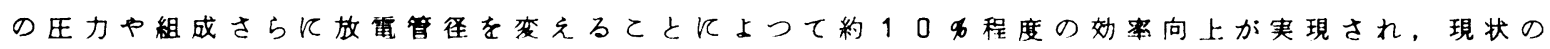

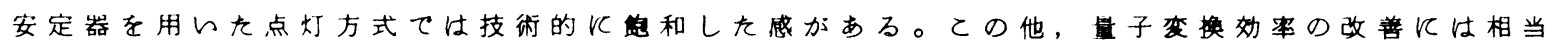

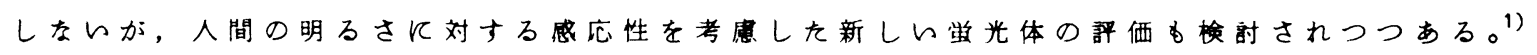

以上の上 5 亿, 徉来の安定器を用的九点灯方式ては, 高奻率化と的観点加ら見ると, それ程

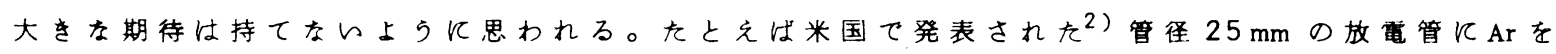

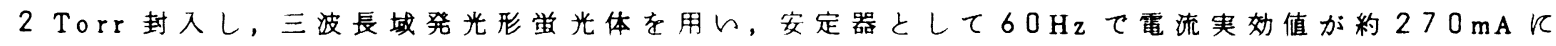

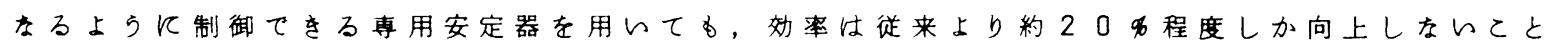
加明らかてある。

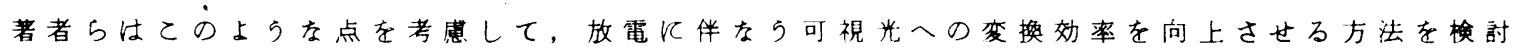

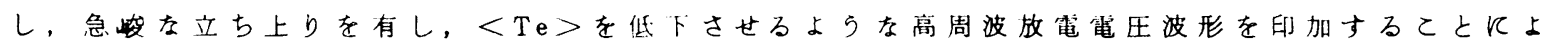
つて著しい高奻率化を実現てきるととを発見したのて報告する。

\title{
2. 研究の背贯
}

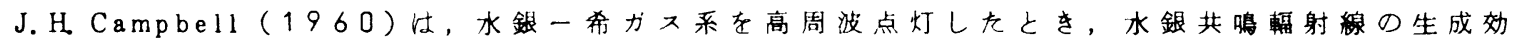

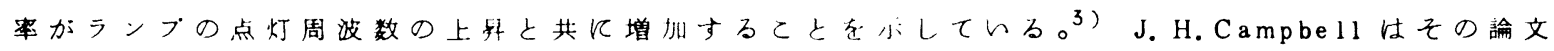

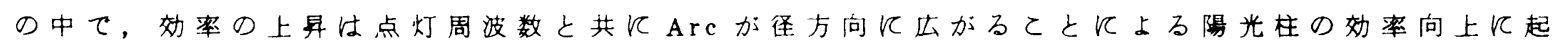

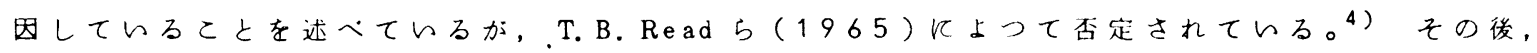

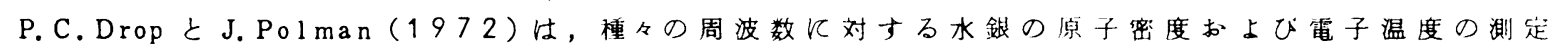

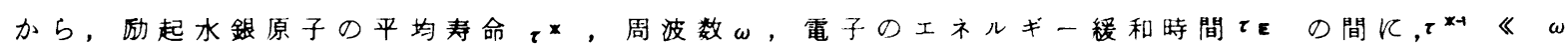

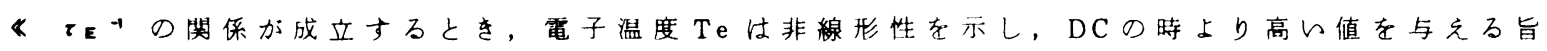

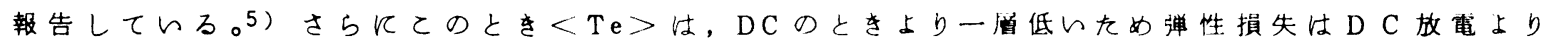
低くなるてとを豭告した。

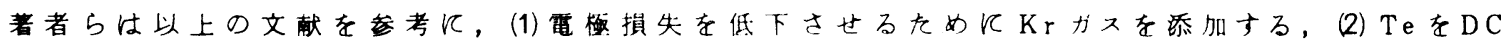

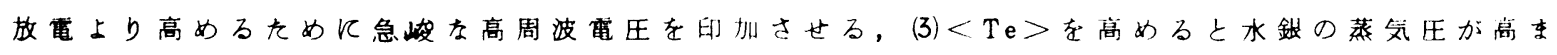

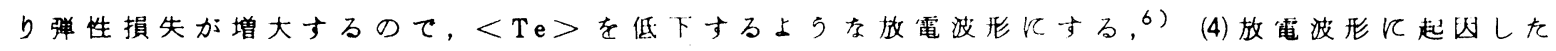

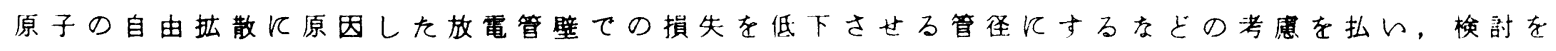
行古った。

\section{3. 結果}

従来の商用点灯方式飞比へ， 約 30 カのランブ奻率向上か 珰められた。

\section{(参考文献)}

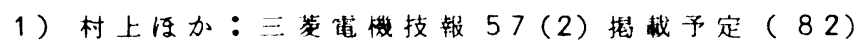

2) C.S. Bessone, et al : IESNA Ann. Tech. Conf ( 82$) \# 17$

3) J. H. Campbell : I 11 um Engng. 55 (1960) 247

4 ) T. B. Read, etal : Br. J. Appl. Phys. 16 (1965) 453

5) 6) P. C. Drop \& J. Polman: J. Phys D 5 (1972) $562: 266$ 